\title{
The Learners' Attitudes towards Using Different Learning Methods in E-Learning Portal Environment
}

\author{
http://dx.doi.org/ijet.v6i3.1610 \\ Issham Ismail, Rozhan M. Idrus, Hanysah Baharum, Munirah Rosli and Azidah Abu Ziden \\ Universiti Sains Malaysia, Penang, Malaysia
}

\begin{abstract}
This study investigates the learners' attitudes towards using academic, collaborative and social interaction in e-learning portal environment. Academic interaction consists of interaction between learners and online learning resources such as online reading, online explanation, online examination and also online question answering. Collaborative interaction occurs when learners interact among themselves using online group discussion. Social interaction happens when learners and instructors participate in the session either via online text chatting or voice chatting. The study employed quantitative methodology where data were collected through questionnaire that was administered to 933 distance education students from Bachelor of Management, Bachelor of Science, Bachelor of Social Science and Bachelor of Art. The survey responses were tabulated in a 5-point Likert scale and analyzed using the Statistical Package for Social Science (SPSS) Version 12.0 based on frequency and percentage distribution. The result of the study suggested that among three types of interaction, most of the student prefer academic interaction for their learning supports in elearning portal compared to collaborative and social interaction. They wish to interact with learning content rather than interact with people. They prefer to read and learn from the resources rather than sharing knowledge among themselves and instructors via collaborative and social interaction.
\end{abstract}

Keywords-academic interaction, collaborative interaction, e-learning, and social interaction.

\section{INTRODUCTION}

In the 21 century, people have to learn more than ever before. The rapid development of computer and Internet technologies has dramatically improved the ways of teaching and learning. One of the technology approaches in learning is e-learning. E-learning or electronic learning is known as instructional content or learning techniques eased by electronic technology and it aim at increasing the knowledge, skills and productive capabilities of the learners in a global situation [9]. They mention that e-learning is a collaborative learning process where people learn from one another. According to Stockley, e-learning is the delivery of a learning, training or education program by electronic means [6]. It involves the use of a computer or electronic device such as mobile phone, in some way to provide training, educational or learning material.

Distance education need to establish an e-learning infrastructure that requires the development of a virtual learning environment for a sustainable educational transaction in the electronic medium and cyberspace, it is also known as an E-Learning Portal. E-Learning Portal focuses on guiding students in the broadest sense through a structured learning experience, at the same time test abilities and provides feedback to the student in a personalised and confidential manner [18]. The School of Distance Education (SDE), Universiti Sains Malaysia (USM) has started using technology as learning support tools in their distance learning program. SDE in USM has carried out the video conferencing, forum, lecturer notes and also e-portal in assisting their students. Although the technology was invoked in improving the distance learning program, learning was grounded in structured course module.

In order to improve the implemented program, it is important in triumph over the limitation of traditional distance education by expanding interactivity. Interactivity is defined as a message loop that is initiated and concluded by the student and where the message content must be 'mutually coherent' [19]. From the definition by Yacci, Markett et al. described interactivity as a complete message loop originating from student and returning to the student [3]. E-learning portal allow learners to interact with each other, with instructors or among learners and with learning contents as Moore portrays three key interactions: learner-content, learner-instructor, and learnerlearner [12]. While Liu et al. classify four type of interaction by the medium of communication: face-to-face, computer-mediated, human-computer and simultaneous group [11].

Anderson reviews six types of interaction by extending an earlier discussion by Moore. First is teacher-content interaction. Second is teacher-teacher interaction and finally content-content interaction [1]. Interaction is an important component of learning experience for both in conventional education and distance education. This study focuses on three types of interaction in E-learning portal: academic interaction which occurs between learners and instructors or learners and academic contents, collaborative interaction among learners and social interaction between learners and instructors.

Collaborative interaction occurs when learners interact among themselves. In distance education, collaborative learning generally supported by asynchronous threaded discussion forums and by synchronous chat rooms [4]. Learning with peers can enrich a student's learning experience; however the benefits of collaborative learning apply only to supportive learning teams composed of students who are committed to their peers' learning success [15] 
Social interaction is a natural and powerful way to learn [14]. It occurs between learners and instructors and can generate well-tuned feedback. As supported by Muirhead, this interactivity involves participation by the learners and with their class tutors [13]. Therefore, it can be phone call or chat session or a delayed personal encounter as discussion forum.

\section{RESEARCH METHODOLOGY}

\section{A. Participants}

The participants in the study are the distance learners from School of Distance Education, Universiti Sains Malaysia (USM) enrolled at first, second, third and fourth year-level on a one semester undergraduate university course. Questionnaires were distributed to 1200 selected distance learners from four different programs (Bachelors of Science, Bachelor of Arts, Bachelor of Management and Bachelor of Social Science). Demographically, there were 549 females and 384 males, and the mean age was 28 years old. The total number of questionnaire returned was 933.

\section{B. Instrumentation}

This survey was constructed based on self-administered questionnaire which solicited learners' attitudes toward using difference learning methods in e-learning to facilitate their learning. The questionnaire was designed and validated by expertise from School of Distance Education. The questionnaire contains closed questions related to the student preference towards using different interaction methods in e-learning portal. The questionnaires were distributed to USM students of session 2007/2008 in the School of Distance Education. Respondents were selected randomly and this sample was chosen because it represents a group of individuals who have experienced using e-learning portal and at the same time had accessed resources of e-learning content. The distribution and collection of questionnaires from respondents were conducted within the annual residential intensive course. The survey utilized a 5-point Likert-type scale that allows students to rate their agreement of each item of the survey. In this study, respondents were asked to rate the items correspond to a Likert-type rating scale where $1=$ strongly disagree, $2=$ disagree, $3=$ neutral, $4=$ agree, $5=$ =strongly agree.

\section{Data Analysis}

The questionnaires consist of two sections. Section A covers the respondents' personal background, such as age, gender, ethnic group, education streams and year of study. Section B contains questions on learners' preferences on the interaction activities in e-learning portal. The raw data were analyzed using Statistical Package for Social Science (SPSS) Version 12.0 based on frequency and percentage distribution. Frequencies were run to determine the distribution of the demographic profile and learners' preference on the interaction activities in e-learning portal. The survey comes with 0.912 Cronbach alphas which indicated there was consistency in the instruments.

\section{RESUlTS AND DisCUSSION}

\section{A. Demographic profile of respondent}

This section portrays respondents' background such as gender, age, degree program, year of study and the frequency of using e-learning portal. According to the sex structure, this study observed (Figure 1) that the numbers of female respondents outnumbers males.

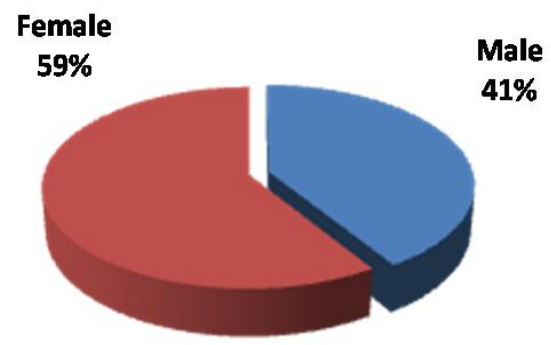

Figure 1. The structure of gender

Depending on the age factor, the result showed from the Figure 2, the respondents being aged between 20 and above 50 years, with and average of 28 years (standard deviation = 7.4). It is noticeable that the category 30-39 years is predominant in distance learning compare with the age categories that exceed 50 years, which are very little represented.

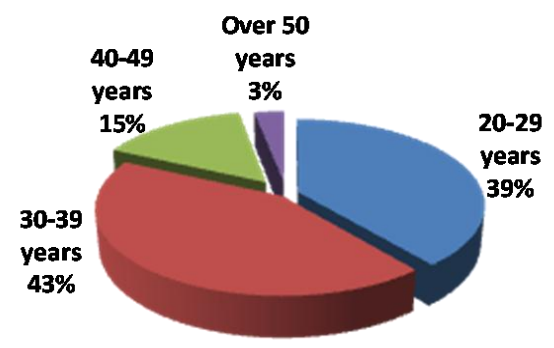

Figure 2. The structure of age

Of the students, $34 \%$ were from Bachelor of Science, $32 \%$ were from Bachelor of Management, 26\% were from Bachelor of Social Science and the remaining balance was from Bachelor of Arts. Most of them enrolled for the first year. About $75 \%$ of the respondents used e-learning portal at least once a week and more than once a week. Only $3 \%$ of the respondents state that they had never used the elearning portal.

B.

B.

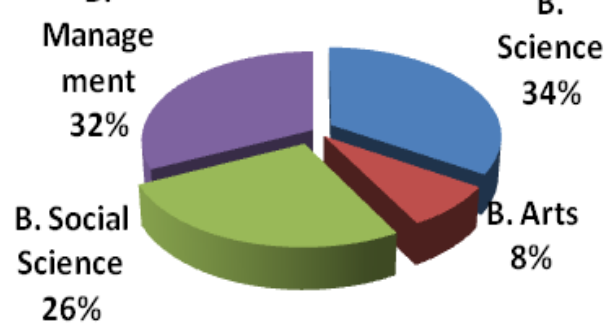

Figure 3. The structure by program

\section{B. Learners' Attitudes Towards Using Different Learning Methods In E-Learning Portal}

Table 1 demonstrated moderate level of attitudes of interaction methods in e-learning portal with mean of 3.42 . The means for items in this factor were in the range of 3.18 to 3.68 . The majority of the respondents agreed that they choose to use online explanation and online question answering, online reading and online chatting (text or voice), online group discussion and online examination and assessment as an interaction methods offered by School of Distance Education. 
TABLE I.

LEARNERS’ ATTITUDES TOWARDS USING DIFFERENT LEARNING METHODS IN E-LEARNING PORTAL

\begin{tabular}{|c|c|c|c|c|}
\hline Category & $\begin{array}{l}\text { Statement } \\
(N=933)\end{array}$ & $\begin{array}{c}\text { Agree/ } \\
\text { Strongly } \\
\text { Agree }\end{array}$ & Mean & Std. Dev \\
\hline \multirow{4}{*}{$\begin{array}{l}\text { Academic } \\
\text { Interaction }\end{array}$} & Online reading & $49.0 \%$ & 3.45 & 0.903 \\
\hline & $\begin{array}{l}\text { Online explana- } \\
\text { tion }\end{array}$ & $60.3 \%$ & 3.68 & 0.858 \\
\hline & $\begin{array}{l}\text { Online examina- } \\
\text { tion and assess- } \\
\text { ment }\end{array}$ & $39.7 \%$ & 3.18 & 1.101 \\
\hline & $\begin{array}{l}\text { Online question } \\
\text { and answer }\end{array}$ & $56.3 \%$ & 3.60 & 0.872 \\
\hline $\begin{array}{l}\text { Collaborative } \\
\text { interaction }\end{array}$ & $\begin{array}{l}\text { Online group } \\
\text { discussion }\end{array}$ & $47.9 \%$ & 3.45 & 0.906 \\
\hline \multirow[t]{2}{*}{$\begin{array}{l}\text { Social Interac- } \\
\text { tion }\end{array}$} & $\begin{array}{l}\text { Online text } \\
\text { chatting }\end{array}$ & $49.7 \%$ & 3.50 & 0.880 \\
\hline & $\begin{array}{l}\text { Online voice } \\
\text { chatting }\end{array}$ & $43.1 \%$ & 3.38 & 0.919 \\
\hline
\end{tabular}

\section{1) Academic Interaction}

\section{a) Learners' attitudes towards online reading}

The mean and standard deviation for learners' attitudes towards online reading was above average (over 3.0) which means that learners had positive attitudes towards reading via online in general. Online reading serves as the source of input for most of the learners in School of Distance Education. Coiro stresses that the new challenges of online learning can have great impact on an individual's ability to comprehend what he or she reads [5]. Anderson found that most of the online reader read academic material online, and other choose online reading for problem solving purpose [11]. The instructors or teachers need to be aware of the online reading strategies that learners use in order to ensure the successfulness of the internet task [10].

b) Learners' attitudes towards online explanation via E-learning portal

Analyzing the students' attitudes towards online explanation as their learning support tool, about $60.3 \%$ of the respondents felt that online explanation able to help them in their learning. It allowed users to more precisely understand the course contents and it may be different from typical everyday understanding.

c) Learners' attitudes towards online examination and assignment

The development of electronic assessment tools and the used of electronic examinations have left behind the initial stage. Shen et al. found collaborative online exam provides flexibility in having multiple resources and comfortable timeframe is less stressful [16]. In this study only $39.7 \%$ out of the questioned students consider that the online learning is suitable to implement in e-learning portal. The majority of the students prefer the traditional method of examination and assessment.

d) Learners' attitudes towards online question and answer
The frequency analysis, demonstrated that $56.3 \%$ of the questioned students agreed/strongly agreed that they simply can use online question answering in e-learning portal. In an online question answering community, participants are able to translate their knowledge, experience and opinions into content [7].

\section{2) Collaborative Interaction}

a) Learners' attitudes towards online group discussion

The students responses regarding the used of online discussion in e-learning portal $47.9 \%$ percent of the respondents prefers to have an online group discussion as a learning support (mean=3.45). Refer to Table 1, youngadult distance learning student have more ability to interact via information technology. This is the reason why so many students preferred the online group discussion as one of their learning method. Thomas' in his study in online discussion assume that the nature of computermediated communication impact student learning [17]. He found that online discussion forums promote high levels of cognitive engagement and critical thinking.

Interaction within forums supports learning and enables the students to provide affective support for each other [2]. Anderson stated that interaction in the class forum is focused on course learning activities and largely initiated by course lecturers; in small group forums, students initiate discussion and report that course activity and social communication freely mix; in the student only forum discussion is largely socially oriented.

\section{3) Social interaction}

a) Learners' attitudes towards online text chatting and online voice chatting

The result from the survey shows that almost half of the respondent consider that online text chatting is suitable for distance learners (refer Table 1). For voice chatting, we observe that $43.1 \%$ out of respondent prefer to use voice chatting in e-learning portal. Geerts in his study found that, text chat is more preferred by younger user and they have more experience with chatting on computers [8]. However, the result show that voice chat is consider more natural and direct, and makes it easier to keep on following the program.

\section{CONCLUSION}

This study demonstrated that by using different learning methods with various interaction activities were influenced learners' attitudes differently. Specifically, the results of the study show that the academic interaction outperformed other group by online explanation and online question answering. The collaborative and social interaction groups contribute more in posting opinions to the discussion board. These findings have some implication for distance learners in their learning process. The interaction with their instructor and peers are important to enhance learning and increase participation in online discussions using e-learning portal. Furthermore, future research needs to be carried out on how collaborative and social interaction will change learners' preference and satisfaction in utilising e-learning portal. Beside that, research is also needed to investigate the affect of online group discussion on learners' performance in their distance learning program. 


\section{ACKNOWLEDGMENT}

The authors would like to acknowledge Universiti Sains Malaysia for the support under RU grant and USM Fellowship scheme.

\section{REFERENCES}

[1] Anderson, N. J. (2003). Scrolling, clicking and reading English: Online reading strategies in a second/foreign language. The Reading Matrix, 3(3).

[2] Anderson, B. (2004). Dimensions of learning and support in an online community. Open Learning, 19(2), 183 - 190.

[3] Markett, C., Arnedillo Sánchez, I., Weber, S. \& Tangney, B. (2006). Using Short Message Service to Encourage Interactivity in the Classroom', Computers \& Education 46(3), 280-93. http://dx.doi.org/10.1016/j.compedu.2005.11.014 doi $>10.1016 /$ j.compedu.2005.11.014

[4] Cakir, M., Xhafa, F., Zhou, N., \& Stahl, G. (2005). Thread-based analysis of patterns of collaborative interaction in chat. Paper presented at The International Conference on AI in Education (AI-Ed 2005), Amsterdam, Netherlands. Retrieved from http://www.cis.drexel.edu/faculty/gerry/pub/aied2005.pdf

[5] Coiro, J. (2003). Reading comprehension on the Internet: Expanding our understanding of reading comprehension to encompass new literacies. The Reading Teacher 56, 458-464.

[6] Stockley, D. (2003). E-learning definition and explanation (Elearning, Online Training, Online Learning). Retrieved March 15,2010 , from http://derekstockley.com.au/elearning-defini tion.html

[7] Gazan, R. (2006). Specialists and synthesists in a question answering community. In Proceedings of the American Society for Information Science \& Technology Annual Meeting 43 (pp. 1-10).

[8] Geerts, D. (2006). Comparing voice chat and text in a communication tool for interactive television. In Proceedings of NordiCHI 2006. ACM, New York, NY, (pp. 461-464). http://dx.doi.org/10.1145/1182475.1182537

[9] Guha, A.S and Maji, S (2008), E-learning: the latest spectrum in open and distance learning, Social Responsibility Journal, 4(3), 297-305. http://dx.doi.org/10.1108/17471110810892820

[10] Leu, D.J. (2002). The new literacies: Research on reading instruction with the Internet and other digital technologies. In A.E. Farstrup \& S.J. Samuels (Eds.), What research has to say about reading instruction (3rd ed., pp. 310-336). Newark, DE: International Reading Association.

[11] Liu, T. C., Wang, H. Y., Liang, J. K., Chan, T. W\& Yang, J. C. (2002). Applying wireless technologies to a build highly interactive learning environment. Paper presented at IEEE international workshop on wireless and mobile technologies in education ,Växjö, Sweden.

[12] Moore, M. G. (1989). Three types of interaction. American Journal of Distance Education, 3(2), 1-6. http://dx.doi.org/10.1080/ $\underline{08923648909526659}$

[13] Muirhead, B. (2000). "Enhancing Social Interaction in ComputerMediated Distance Education." Educational Technology \& Society, 3(4). Available: http://ifets.ieee.org/periodical/vol_4_2000/ v_4_2000.html
[14] Okita SY, Bailenson J, Schwartz DL (2007) The mere belief of social interaction improves learning. In: McNamara DS, Trafton JG (eds) The proceedings of the 29th meeting of the cognitive science society. (pp 1355-1360)

[15] Soller, A., Linton F., Goodman, B., and Lesgold, A., (1999), Toward Intelligent Analysis and Support of Collaborative Learning Interaction, In Proceedings of the Ninth International Conference on Artificial Intelligence in Education. (pp. 75-82)

[16] Shen, J., K.-E.Cheng, ,M. Bieber, and S. R. Hiltz. (2004). Traditional in-class Examination vs. collaborative online examination in asynchronous learning networks: Field evaluation results. In Proceedings, Americas Conference on Information Systems 2004, New York City, NY.

[17] Thomas, M. J. W. (2002). Learning within incoherent structures: The space of online discussion forums. Journal of Computer Assisted Learning, 18, 351-366.

[18] Walker, C. (2006). Types of portal: a definition. Retrieved March 10, 2010, from http://www.steptwo.com.au/papers/cmb_portaldefi nitions/index.html

Yacci, M. (2000). Interactivity demystified: A structural definition for online learning and intelligent CBT. Educational Technology. Retrieved March 16, 2010 from http://www.it.rit.edu/ may/interactiv8.pdf

\section{AUTHORS}

Issham Ismail is with the School of Distance Education, Universiti Sains Malaysia, Minden, Pulau Pinang, 11800 Malaysia (e-mail: issham@usm.my)

Rozhan M. Idrus is with the School of Distance Education, Universiti Sains Malaysia, Minden, Pulau Pinang, 11800 Malaysia. He is specialized in Open and Distance Learning Interactive Technologies and e-Learning (e-mail: rozhan@usm.my).

Hanysah Baharum is a student in the School of Distance Education, Universiti Sains Malaysia, Minden, Pulau Pinang, 11800 Malaysia and currently doing her master in Educational Technology in Universiti Sains Malaysia. (e-mail: hanysahbaharum@gmail.com).

Munirah Rosli is a student in the School of Distance Education, Universiti Sains Malaysia, Minden, Pulau Pinang, 11800 Malaysia and currently doing her master in Educational Technology in Universiti Sains Malaysia.

(e-mail: munirahrosli@yahoo.com.my).

Azidah Abu Ziden is with the School of Education Studies, Universiti Sains Malaysia, Minden, Pulau Pinang, 11800 Malaysia (e-mail: azidah@usm.my)

This work was supported in part by the Universiti Sains Malaysia under RU Grant 1001/PJJAUH/817015.

Received January, 17, 2009. Published as resubmitted by the authors August 2 ${ }^{\text {nd }}, 2011$. 